\title{
STUDI KUALITAS KIMIA DAN SENSORIK IKAN PINDANG BANDENG (Chanos chanos Forskal) TANPA DURI YANG DISIMPAN DALAM KEMASAN VAKUM SUHU AMBIENT
}

\author{
Study of Chemical and Sensory Quality of Pindang \\ Thorns Leave Milkfish (Chanos chanos, Forskal) Storing in Vacuum Packaging at Ambient Temperature \\ Rahdi Fajar Miftahulkhair*, Andi Besse Patadjai, Suwarjoyowirayatno \\ Jurusan Teknologi Hasil Perikanan, Fakultas Perikanan dan Ilmu Kelautan Universitas Halu Oleo, Kendari, \\ Sulawesi Tenggara, Indonesia \\ *Email korespondensi: rahdifajar@gmail.com (Telp: +6282144446819) \\ Diterima: 16 April/ Disetujui 27 Juli 2020
}

Cara sitasi: Miftahulkhair RF, Patadjai AB, Suwarjoyowirayatno. 2020. Kandungan TVB dan TMA ikan pindang bandeng (Chanos chanos Forskal) tanpa duri yang disimpan pada suhu ambient dalam kemasan vakum. Jurnal Fish Protech. 3(2):165-171.

\begin{abstract}
The aim of this study was to determine the effect on freshness quality of thorns leave milkfish storing at ambient temperature in vacuum packaging. This study used a non factorial randomized design (CRD) whichwas storage time consisting of 4 treatments $\mathrm{HO}$ (0 days), $\mathrm{H} 2$ (2 days), $\mathrm{H} 4$ (4 days) and $\mathrm{H} 6$ (6 days). Each treatment was carried out with 3 times replication. Based on the test results, it showed that the difference in different storage duration significantly affected on freshness value of fish (TVB and TMA) of thorns leave milkfish at ambient temperature, along with the time of storage of vacuum packaged fish, the value of TVB and TMA increased.On the 6th day of storage (H6) had the highest TVB and TMA values of $24.40 \mathrm{mgN} / 100 \mathrm{~g}$ and $3.43 \mathrm{mgN} / 100 \mathrm{~g}$, respectively.
\end{abstract}

Keywords: milkfish leave thorns, pindang, sensory, vacuum.

\begin{abstract}
ABSTRAK
Tujuan dari penelitian ini adalah untuk mengetahui nilai kesegaran ikan pindang bandeng tanpa duri kemasan vakum pada suhu ambient. Penelitian ini menggunakan rancangan percobaan adalah Rancangan Acak Lengkap (RAL) non faktorial yakni waktu penyimpanan yang terdiri dari 4 perlakuan yaitu $\mathrm{HO}$ ( 0 hari), $\mathrm{H} 2$ (2 hari), H4 (4 hari) dan H6 (6 hari). Masing-masing perlakuan dilakukan sebanyak tiga kali pengulangan, sehingga diperoleh jumlah satuan percobaan sebanyak 12 unit. Berdasarkan hasil pengujian, perbedaan lama penyimpanan berbeda secara signifikan mempengaruhi nilai kesegaran ikan (TVB dan TMA) bandeng tanpa duri yang disimpan pada suhu ambeien, seiring dengan waktu penyimpanan ikan pindang bandeng tanpa duri kemasan vakum, nilai TVB dan TMA meningkat. Pada hari ke 6 penyimpanan (H6) memiliki nilai TVB dan TMA tertinggi masing-masing $24,40 \mathrm{mgN} / 100 \mathrm{~g}$ dan $3,43 \mathrm{mgN} / 100 \mathrm{~g}$.
\end{abstract}

Kata kunci: ikan bandeng tanpa duri, pindang, vakum

\section{PENDAHULUAN}

Ikan bandeng (Chanos chanos, Forskal) merupakan salah satu komoditas yang strategis untuk memenuhi kebutuhan protein yang relatif murah dan digemari oleh konsumen di Indonesia. Pamijiati (2009) menyatakan bahwa ikan bandeng banyak digemari oleh sebagian besar masyarakat Indonesia karena memiliki kandungan gizi tinggi dan protein yang lengkap dan penting untuk tubuh.

Komoditas ikan bandeng sangat mudah mengalami kemunduran mutu (pembusukan) sehingga perlu upaya untuk mengetahui karakteristik dari daging ikan bandeng dari komposisi kimia yang meliputi proksimat, asam amino, asam lemak, mineral 
dan vitamin. Informasi tersebut akan bermanfaat dalam pemanfaatan sumber daya ikan bandeng sebagai pemenuhan kebutuhan bahan pangan masyarakat.

Salah satu cara untuk mempertahankan kualitas ikan bandeng, maka dilakukan proses pindang. Berdasarkan urutan disposisi dalam pengolahan tradisional, produk ikan pindang menduduki posisi kedua setelah ikan asin (Ariyani dan Yennie, 2008). Pengolahan ikan pindang secara tradisional biasanya kurang memerhatikan aspek sanitasi dan higiene sehingga menyebabkan rendahnya mutu simpan dan keamanan ikan pindang (Jenie et al., 2001). Jenis kemasan dapat berpengaruh dalam masa penyimpanan, dimana kemasan yang kurang rapat akan memudahkan keluar masuknya gas dan uap air, sehingga mengakibatkan terjadinya penurunan mutu produk akibat reaksi oksidasi, dan tumbuhnya mikroba pathogen serta absorpsi aroma selama masa penyimpanan.

Produk perikanan mempunyai sifat yang mudah rusak atau membusuk, sehingga produk perikanan tidak akan bertahan lama bila disimpan dan jangkauan pemasarannya sangat terbatas. Pembentukan senyawa TVB pada ikan selama penyimpanan mengalami kenaikan disamping formaldehid, TMAO dan TMA. Hal ini disebabkan karena selama proses kemunduran mutu ikan akan terbentuk basa-basa volatile akibat dekomposisi protein oleh aktivitas bakteri dan enzim.TVB merupakan senyawa hasil degradasi protein yang menghasilkan sejumlah basa yang mudah menguap seperti amoniak, histamin, hidrogen sulfida, dan trimetilamin yang berbau busuk (Liu et al., 2010).

Kemasan vakum adalah sistem pengemasan hampa udara dimana tekanannya kurang dari $1 \mathrm{~atm}$ dengan cara mengeluarkan $\mathrm{O}_{2}$ dari kemasan sehingga memperpanjang umur simpan ikan pindang. Berdasarkan hasil penelitian Fitria et al., (2002) diperoleh kesimpulan bahwa faktor proses Rancangan Penelitian

Rancangan percobaan yang digunakan adalah Rancangan Acak Lengkap (RAL) non faktorial yakni waktu penyimpanan yang terdiri dari 4 perlakuan yaitu pengemasan (vakum dan non vakum) dan faktor umum simpan (nol minggu hingga 10 minggu) tidak mempengaruhi kadar lemak, protein, air pada pengolahan ikan.

Suhu ambien adalah istilah yang mengacu pada suhu kamar atau suhu yang mengelilingi sebuah obyek tersebut yakni 20-250C. Menurut Marhamah (2011) masa simpan tergantung pada kondisi penyimpanan dalam hal ini suhu penyimpanan. Produk yang disimpan pada suhu $25^{\circ} \mathrm{C}$ tanpa kemasan vakum hanya bertahan 1 hari sementara produk yang disimpan pada suhu $0^{\circ} \mathrm{C}-5^{\circ} \mathrm{C}$ tanpa kemasan vakum mampu bertahan selama 30 hari.

Olehnya itu, untuk meningkatkan nilai jual dan nilai ekonomi ikan bandeng, maka akan dilakukan pencabutan duri yg terdapat dalam ikan bandeng. Usaha produksi ikan bandeng tanpa duri memiliki ini prospek sangat cerah dan dapat terus dikembangkan. Berdasarkan hal-hal tersebut di atas, maka akan dilakukan penelitian tentang studi kualitas kimia dan sensorik ikan pindang bandeng tanpa duri yang disimpan dalam kemasan vakum suhu ambien.

\section{Alat dan Bahan}

\section{METODE PENELITIAN}

Alat yang digunakan pada penelitian ini adalah cawan conway bulp, zentrifugen (hetticle), vortex maxi (thermo), corong (herma), buret (pirex) elenmeyer, kompor listrik, mortal, tabung reaksi, timbangan analitik, rak tabung reaksi, kuvet, baki, porselin, tanur, batang pengaduk, gelas beaker, gegep, desikator, labu ukur, oven, soxlet, kjhendal, spatuladan gunting.

Bahan baku utama yang digunakan dalam penelitian ini adalah ikan bandeng diperoleh dari tambak yang berada di Kec. Tinanggea, Kab. Konawe Selatan.Bahan yang digunakan untuk uji TVB dan TMA yaitu Tricloroacetic Acid (TCA) $7 \%, \mathrm{H}_{3} \mathrm{BO}_{3}$, $\mathrm{K}_{2} \mathrm{CO}_{3}$ jenuh, $\mathrm{HCl} 0,021 \mathrm{~N}$, kertas saring, indikator Tashiro.

H0 (0 hari), H2 (2 hari), H4 (4 hari) dan H6 (6 hari). Masing-masing perlakuan dilakukan 3 kali ulangan, sehingga diperoleh jumlah satuan percobaan sebanyak 12 unit. 
Penelitian ini menggunakan Rancangan Acak Lengkap (RAL) non faktorial, dimana data yang diperoleh berasal dari uji kimia menggunakan analisis keragaman (ANOVA) dan apabila terdapat perbedaan maka dilanjutkan dengan uji DMRT (Duncan Multiple Range Test)dengan tingkat kepercayaan 95\%.

\section{Pencabutan duri bandeng}

Cara pembuangan sisik dengan dikerok dari pangkal ekornya menuju ke bagian kepala dengan pisau atau pembuang sisik (khusus). Teknik pembelahan (fillet) dengan cara menyayat bagian punggung ikan dengan menggunakan pisau. Penyayatan dimulai dari bagian ekor sampai dengan membelah kepala dan selanjutnya dilakukan pembuangan isi perut serta insang. Ikan yang difillet dicuci bersih dengan menggunakan air bersih untuk menghilangkan sisa darah, lemak maupun kotoran yang masih menempel.

Buang tulang punggung menggunakan pisau dari bagian ekor hingga bagian kepala. Cabut tulangtulang dari permukaan dinding perut, pada bagian perut terdapat 16 pasang tulang besar. Buat irisan memanjang pada guratan daging punggung bagian tengah dan bagian perut dengan menggunakan ujung pisau. Irisan dilakukan dengan hati-hati agar duri-duri tidak terputus, selanjutnya pencabutan duri dilakukan dengan cara memasukkan ujung pinset pada bagian irisan tersebut, kemudian dilakukan pencabutan satu persatu, pada bagian punggung terdapat 42 pasang duri bercabang yang berada di dalam daging dekat kulit luar. Sepanjang lateral line terdapat 12 pasang duri cabang, sedangkan di bagian perut terdapat 12 pasang duri. Rendemen ikan bandeng yang telah dibuang durinya sebesar $70-80 \%$.

\section{Proses Pemindangan Ikan Bandeng Tanpa Duri}

Setelah ikan segar diperoleh, disiangi ikan dicuci dengan air mengalir sampai bersih, kemudian diatur dalam wadah (panci). Satu wadah diisi dengan 3 ekor ikan bandeng. Kepala ikan yang satu bersisian dengan bagian ekor ikan yang lain dengan tidak timpang tindih. Setelah itu wadah berisikan ikan bandeng ditambahkan larutan garam $8 \%$. Setelah 20 menit direbus dengan suhu $105^{\circ} \mathrm{C}$ (dihitung dari saat larutan garam mendidih setelah wadah berisi ikan dimasukkan), ditiriskan \pm 30 menit, kemudian disimpan pada suhu ambient.

\section{Pengemasan dan penyimpanan ikan bandeng tanpa duri}

Adapun cara pengemasan dan penyimpanan ikan bandeng tanpa duri yang dilakukan adalah menggunakan plastik jenis polyethylene dengan ketebalan 0,05-0,07 mm dan lebar $11-12 \mathrm{~cm}$ dimasukkan ikan bandeng tanpa duri setelah itu divakum pada tekanan $10^{-2} \mathrm{~Pa}$ selama 60 detik kemudian disimpan pada suhu ambien selama 0, 2, 4, dan 6 hari.

\section{HASIL DAN PEMBAHASAN}

Hasil analisis sidik ragam nilai TVB dan TMA menunjukkan perbedaan signifikan $\left(F_{h i t}>F_{\operatorname{tab}(0,05)}\right)$. Hasil pengujian TVB da TMA dapat dilihat pada Tabel 1.

Tabel 1. Hasil Pengujian TVB dan TMA.

\begin{tabular}{lcccc}
\hline \multirow{2}{*}{ kimia } & \multicolumn{4}{c}{ Rerata \pm SD } \\
\cline { 2 - 5 } & $\mathrm{H} 0$ & $\mathrm{H} 2$ & $\mathrm{H} 4$ \\
\hline TVB & $11,44^{\mathrm{a}} \pm 0,749$ & $14,57^{\mathrm{b}} \pm 0,047$ & $20,37^{\mathrm{c}} \pm 0,589$ & $20,37^{\mathrm{d}} \pm 0,754$ \\
TMA & $0,38^{\mathrm{a}} \pm 0,327$ & $1,17^{\mathrm{b}} \pm 1,171$ & $3,27^{\mathrm{c}} \pm 3,268$ & $3,43^{\mathrm{c}} \pm 3,431$ \\
\hline Keterangan: Notasi huruf yang sama menunjukkan hasil berbeda tidak nyata dengan taraf signifikan ( $\mathrm{a}=5 \%)$.
\end{tabular}




\section{TVB-N}

Hasil analisis sidik ragam menunjukkan bahwa terdapat perbedaan yang nyata ( $\left.F_{\text {hit }}>F_{\text {tab }}(0,05)\right)$ pada nilai TVB-N. Tabel 1 menunjukkan bahwa seiring dengan lamanya waktu penyimpanan, nilai TVB-N semakin meningkat. Pada penyimpanan $\mathrm{H} 0$ hingga $\mathrm{H} 6$ menunjukkan nilai uji TVB-N rata-rata berturut-turut berada di kisaran 11,$44 ; 14,57 ; 20,37$; dan 24,40 . Nilai TVB-N pada semua perlakuan sangat rendah. Hal ini mengindikasikan bahwa kemunduran mutu dari produk ikan pindang bandeng tanpa duri dapat dihambat dengan cara dikemas secara vakum. Nasution et al. (2017) menjelaskan nilai TVB-N ikan asap pada minggu pertama hingga minggu kedua penyimpanan yang dikemas secara vakum adalah 17 - $20 \mathrm{mgN} / 100 \mathrm{gr}$ lebih rendah dari pada ikan yang dikemas secara nonvakum yaitu 18 - $24 \mathrm{mgN} / 100 \mathrm{gr}$. Hal ini menunjukkan bahwa kemasan vakum lebih efektif menghambat aktifitas bakteri pembusuk dibandingkan dengan yang dikemas non vakum.

Lebih lanjut pada penelitian Ozpolat et al. (2014) yang menyatakan bahwa nilai TVB-N sosis ikan yang dikemas vakum lebih rendah dibandingkan yang tidak dikemas vakum. Hal ini dikarenakan ketersediaan oksigen di dalam kemasan non vakum lebih besar dibandingkan dengan kemasan vakum. Oksigen akan meningkatkan aktivitas mikroorganisme aerob terutama bakteri yang merombak protein menjadi senyawa yang menghasilkan bau yang tidak diinginkan seperti $\mathrm{H}_{2} \mathrm{~S}$, ammonia dan indol (Nur, 2009). Kandungan TVB-N maksimal adalah 30 $\mathrm{mgN} / 100 \mathrm{~g}$ (Idakwo et al., 2016). Berdasarkan nilai TVB-N bandeng presto baik yang dikemas vakum maupun nonvakum masih di bawah batas maksimal, sehingga sampai pada penyimpanan hari keenam bandeng presto masih layak dikonsumsi.

Nilai TVB-N pada penyimpanan $\mathrm{HO}$ memiliki nilai terendah $\quad(11,44 \mathrm{mgN} / 100 \mathrm{~g})$ kemudian berangsur-angsur meningkat pada lama penyimpanan berikutnya berturut-turut $(14,57 \mathrm{mgN} / 100 \mathrm{~g}),(20,37$ $\mathrm{mgN} / 100 \mathrm{~g})$ dan $(24,40 \mathrm{mgN} / 100 \mathrm{~g})$ masing-masing untuk H2, H4 dan H6. Meskipun dikemas secara vakum dan disimpan pada suhu ambien produk ikan pindang akan tetap mengalami penurunan mutu seiring berjalannya waktu penyimpanan. Hal ini diduga karena ikan mengalami dekomposisi. Semakin banyak daging hasil perikanan terdekomposisi maka semakin banyak pula ammonia yang dihasilkan. Hal serupa juga terjadi pada penelitian Ariyani et al. (2004) pada suhu kamar, kenaikan nilai TVB terjadi setelah 6 hari penyimpanan (15 - $40 \mathrm{mgN} / 100 \mathrm{~g})$. Lebih lanjut dijelaskan kenaikan kadar TVB ikan pindang secara nyata setelah beberapa minggu disimpan pada suhu dingin $(15-45 \mathrm{mgN} / 100 \mathrm{~g})$.

Pada awal masa penyimpanan hingga beberapa hari masa penyimpanan pada umumnya peningkatan kadar TVB dikarenakan oleh bertambahnya jumlah bakteri kontaminasi sehubungan dengan semakin berlanjutnya proses kemunduran mutu oleh mikroorganisme yang menghasilkan basa yang mudah menguap seperti amoniak (Botta, 1995). Lebih lanjut dijelaskan oleh Suwetja (2013) peningkatan kadar TVB terjadi akibat adanya perombakan protein atau asam-asam amino sehingga menghasilkan sejumlah basa yang mudah menguap, antara lain amoniak $\left(\mathrm{NH}_{3}\right)$, dimetilamin (DMA), monometilamin (MMA), hidrogen sulfida $\left(\mathrm{H}_{2} \mathrm{~S}\right)$ dan trimetilamin (TMA) karena adanya perombakan trimetilamin oksida (TMAO) (Suwetja, 2013).

Nilai TVB pada hari ke-6 (H6) yaitu $24,40 \mathrm{mgN} / 100 \mathrm{~g}$ hasil yang berbeda ditunjukan pada penelitian Aryansyah (2020) dimana sampel pempek ikan barakuda yang disimpan dalam retortable pouch penyimpanan suhu ambeient menunjukkan peningkatan kadar TVB hingga hari ke-12 (T3) dengan kadar TVB 12,48 mgN/100g. Perbedaan nilai TVB ini dipengaruhi oleh proses sterilisasi komersial pada pempek yang dikemas retortable pouch. Sesuai dengan peryataan Nurhikmat (2014) sterilisasi adalah operasi yang penting dalam proses pengalengan makanan bertujuan untuk menghancurkan mikroba pembusuk dan pathogen penyebab kerusakan pangan. Perlu diketahui terjadinya pemecahan protein menjadi TVB, kandungan protein yang tinggi pada produk perikanan dan kondisi lingkungan yang sangat memungkinkan untuk pertumbuhan mikroba pembusuk selama penyimpanan merupakan salah satu faktor terbentuknya TVB. 
Nilai TVB dari awal hingga akhir masa penyimpanan ikan pindang yang disimpan pada suhu ambeient berkisar 11,44 mgN/100g hingga 24,40 $\mathrm{mgN} / 100 \mathrm{~g}$ berbeda dengan Faisal (2020) pada sampel ikan bandeng kemasan vakum penyimpanan suhu $5^{\circ} \mathrm{C}$ hari ke-0 yaitu $4,793 \mathrm{mgN} / 100 \mathrm{~g}$ kemudian meningkat menjadi $8,061 \mathrm{mgN} / 100 \mathrm{~g}$ pada hari ke-7. Nilai TVB ikan pindang bandeng pada penyimpanan hari ke-6 relatif lebih tinggi daripada ikan bandeng yang disimpan pada suhu $5^{\circ} \mathrm{C}$, hal ini dikarenakan suhu dingin dapat mempertahankan daging ikan bandeng agar tidak banyak mengalami dekomposisi selama proses penyimpanan. Apabila semakin banyak daging ikan terdekomposisi, maka semakin banyak pula ammonia yang dihasilkan sehingga berdampak pada kadar TVB yang dihasilkan. Hal ini didukung oleh penelitian Clucas dan Ward (1996) yang menyatakan bahwa suhu rendah0- $6^{\circ} \mathrm{C}$ menyebabkan aktivitas mikroorganisme danenzim penyebab pembusukan akan terganggu sehinggapembentukan basa volatil nitrogen yang diduga akibat reaksi kimia setelah proses post rigor mortis dan aktivitas bakteri juga akan terganggu. Indikator kesegaran udang menurun adalah kandungan nitrogen yang mudah menguap akan meningkat yang ditandai dengan peningkatan kadar TVB-N.

Untuk produk hasil perikanan yang belum diolah batas nilai TVB-N menurut Commision Regulation (2008) dalam Ruiz-Capillas et al. (1998) yang ditolerir paling banyak $35 \mathrm{mgN} / 100 \mathrm{~g}$. Nilai TVB pada semua perlakuan masih berada jauh dibawah batas $35 \mathrm{mgN} / 100 \mathrm{~g}$, dimana ikan pindang tersebut masih sangat layak untuk dikonsumsi. Menurut Raeisi et al. (2016) kadar TVB-N yang direkomendasikan untuk penolakan adalah $20 \mathrm{mgN} / 100 \mathrm{~g}$. Ketika konsentrasi TVB-N melebihi $30 \mathrm{mg} / 100 \mathrm{~g}$ daging, produk hasil perikanan tersebut harus dipertimbangkan bila layak untuk dikonsumsi.

\section{TMA-N}

TMAO secara alami terdapat pada serat daging hewan perairan. Jika hewan perairan mengalami kematian maka TMAO tereduksi menjadi TMA akibat adanya aktivitas enzim. Reaksi ini berperan penting dalam pembusukkan hasil perikanan yang disebabkan oleh bakteri. TMA merupakan salah satu senyawa volatil yang dapat dijadikan indikator kesegaran hewan perairan (Botta, 1990). Nilai TMA-N rendah dari 0 hari penyimpanan $(\mathrm{HO})$ yaitu 0,38 $\mathrm{mgN} / 100 \mathrm{~g}$ kemudian berangsur-angsur meningkat hingga hari ke-6 (H6) menjadi $3,43 \mathrm{mgN} / 100 \mathrm{~g}$. Banyak ahli berpendapat bahwa batasan kesegaran hasil perikanan yang dinilai dengan uji TMA adalah 5 $\mathrm{mgN} / 100 \mathrm{~g}$ daging (Montgomery et al., 1970 dalam Suwetja 1992). Menurut Suwetja (2011) TMA akan terhambat pembentukkannya pada hasil perikanan apabila dibekukan akan tetapi menurut Hebard et al. (1982) TMA tidak dapat terbentuk dalam kadar yang cukup pada reaksi enzimatis, sama halnya dengan pembentukkan DMA dan FA.

Kadar TMA ikan pindang bandeng meningkat hingga hari ke-6 (H6) menjadi $3,43 \mathrm{mgN} / 100 \mathrm{~g}$ Sebagai pembanding pada penelitian Faisal (2020) penyimpanan suhu $5^{\circ} \mathrm{C}$ ikan badeng hari ke-6 kandungan TMA terjadi peningkatan pada semua perlakuan, pada penyimpanan hari ke-6 kandungan TMA yang terendah pada perlakuan kemasan vakum yaitu $1,2 \mathrm{mgN} / 100 \mathrm{~g}$ selanjutnya pada perlakuan kemasan nonvakum yaitu $2,015 \mathrm{mgN} / 100 \mathrm{~g}$, kemudian tertinggi sampel tanpa kemasan yaitu $3,322 \mathrm{mgN} / 100$ $\mathrm{g}$, rendahnya nilai TMA ini kemungkinan disebabkan makromolekul protein belum sepenuhnya terurai menjadi trimetilamin ammonia.

Menurut Farahita et al. (2012) seiring bertambahnya waktu penyimpanan kandungan TMA akan meningkat dengan proses penguraian makromolekul (protein) menjadi trimetilamin. Lebih lanjut dijelaskan, penguraian protein pada ikan akan menghasilkan senyawa trimetilamin dan ammonia. Ikan darat lebih banyak menghasilkan amonia, sedangkan ikan laut akan menghasilkan lebih banyak trimetilamin (Hadiwiyoto, 1993).Banyak ahli berpendapat bahwa batasan kesegaran hasil perikanan yang dinilai dengan uji TMA adalah 5 $\mathrm{mgN} / 100 \mathrm{~g}$ daging (Suwetja, 2013).

TMA merupakan bagian dari TVB oleh sebab itu kandungan TMA selalu lebih rendah dari TVB. TMA merupakan hasil dari reduksi TMAO oleh enzim. Pada 
kasus pembusukan ikan, mikroorganisme memanfaatkan atom oksigen yang disumbangkan oleh TMAO dalam kondisi anaerob dan mengakibatkan peningkatan pembentukan TMA (Adams dan Moss, 2008). Jenis mikroba yang berperan pada proses pembusukan ikan sebagian besar terdiri dari bakteri gram-negatif dari jenis Pseudomonas, Alteromonas, Shewanella, Moraxella, Acinetobacter, Vibrio, Flavobacterium dan Cytophaga.

\section{KESIMPULAN}

Berdasarkan hasil penelitian dan pembahasan diatas, maka dapat disimpulkan seiring lamanya waktu penyimpanan ikan pindang kemasan vakum yang disimpan dengan suhu ambient maka nilai
TVB dan TMA akan mengalami peningkatan. Pada penelitian ini dengan penggunaan kemasan vakum maka peningkatan kadar TVB dan TMA dari produk ikan bandeng pindang cabut duri temperatur ambient dapat bertahan hingga penyimpanan hari ke-6 ditandai dengan nilai TVB dan TMA penyimpanan hari ke-6 (H6) berturut-turut 24,40 $\mathrm{mgN} / 100 \mathrm{~g}$ dan 3,43 $\mathrm{mgN} / 100 \mathrm{~g}$ yang dimana nilai tersebut termasuk masih layak dan aman untuk dikonsumsi. Meskipun masih tergolong untuk layak dan aman untuk dikonsumsi namun penyimpanan lebih lama dari pada produk itu tidak menutup kemungkinan sudah tidak dapat digunakan untuk mempertahankan masa simpan ikan pindang.

\section{DAFTAR PUSTAKA}

Adams MR, Moss MO. 2008. Food Microbiology, 3rd Edition. Cambridge: RSC Pub.

Ariyani F, Yulianti dan Martati T. 2004. Studi perubahan kadar histamin pada pindang tongkol (Euthynnus affinis) selama penyimpanan. $\mathrm{J}$ Penelitian Perikanan Indonesia, 10(3): 27-46.

Aryansyah D, 2020. Studi Perubahan Kimia, Fisika dan Sensorik Pempek Surimi Barakuda (Sphyraena Barracuda) Pasca Sterilisasi dalam Retortable Pouch pada Penyimpanan Suhu Ambient. Skripsi. Kendari: Universitas Halu Oleo

Botta JR. 1995. Freshness Quality of Seafoods. Chemistry, Processing Technology and Quality, Jurnal of Spinger. Pp 140-167

Clucas \& Ward 1996. Fish Handling, Preservation and Processing in the Tropic Part. 1. Tropical Product Institute, London.

Faisal. 2020. Studi Kimia Ikan Bandeng (Chanos Chanos) Tanpa Tulang yang Dikemas Menggunakan Metode Kemasan Berbeda pada Penyimpanan Suhu Dingin $\left(5^{\circ} \mathrm{C}\right)$. Skripsi. Semarang: Universitas Diponegoro.

Farahita Y, Junianto, Kurniawati N. 2012. Karakteristik Kimia Caviar Nilem dalam Perendaman Campuran Larutan Asam Asetat dengan Larutan Garam selama Penyimpanan Suhu
Dingin $\left(5-10^{\circ} \mathrm{C}\right)$. Jurnal Perikanan dan Kelautan ISSN: 2088-3137, 3(4): 165-170. Unpad.

Hadiwiyoto. 1993. Teknologi Hasil Perikanan. Jilid 1. Yogyakarta: Penerbit. Liberty. Ilyas. 1983. Teknologi Refrigasi Hasil Perikanan. Jilid 1. Jakarta: CV Paripurna.

Hebard, CE, Flick GJ and Martin RE. 1982 Occurance and Significance of Trimethylamine oxide and its devartives in fish and shellfish. In Chemistry and Biochemistry of Marine Food Products p149. AVI Publishing Company Westport. Connecticut.

Idakwo PY, Negbenebor CA, Badau MH, Gbenyi DI. 2016. Total volatile base nitrogen (TVBN) and trimethylamine (TMA) content of "Bunyi youri" as influenced by the addition of glucose and clove during storage. International Journal of Biotechnology and Food Science Vol. 4(5), pp. 81-85, December 2016.

Jenie BS, Nuratifa, Suliantari. 2001. Peningkatan Keamanan Pangan dan Mutu Simpan Pindang Kembung (Rastrelliger $\mathrm{sp}$ ) dengan Aplikasi Kombinasi Natrium Asetat, Bakteri Asam Laktat dan Pengemasan Vakum. Jurnal Teknologi Industri Pangan, Vol. XII No. 1. 2001.

Liu S, Fan W, Zhing S, Ma C, Li P, Zhou K, Peng Z, Zhu M. 2010. Quality evaluation of tray- 
packed tilapia fillets st ored at $0^{\circ} \mathrm{C}$ based on sensory, microbiological, biochemical and physical attributes. African Journal of Biotechnology, 9(5), 692-701.

Nasution SAR, Hasan B, Leksono T 2017. Pengaruh pengemasan vakum terhadap perubahan mutu sensoris, kimia dan mikrobiologi ikan baung (Hemibagrus nemurus) asap yang disimpan pada suhu dingin $\left(5 \pm 1^{\circ} \mathrm{C}\right)$. Unsri

Nurhikmat A,Kurniadi $M$, Kusumaningrum $A$, Susanto A. 2019. Proses Termal Dan Pendugaan Umur Simpan Nasi Goreng Dalam Kemasan Retort Pouch. Jrti Vol.13 No.1 Juni 2019.

Nur, M., 2009. Pengaruh Cara Pengemasan, Jenis Bahan Pengemas, Dan Lama Penyimpanan Terhadap Sifat Kimia, Mikrobiologi, Dan Organoleptik Sate Bandeng (Chanos Chanos). Ozpolat E, Patir BB, Guran S., 2014. Effect of vacuumpacking method on the shelf -life of Capoeta umbla sausages. Iranian Journal of Fisheries Sciences. 13(1):178-184.

Pamijiati, 2009. Pengaruh ekstrak daun selasih (Ocimum basilicum Linn) terhadap mutu kesegaran ikan bandeng selama penyimpanan dingin (Chanos chanos Forsk). Skripsi. Semarang: Universitas Diponegoro.

Raeisi S, Sharifi-Rad M, Quek SY, Shabanpour B and Sharifi-Rad J. 2016. Evaluation of Antioxidant and Antimicrobial Effects of Shallot (Allium ascalonium L.) Fruit and Ajwain (Trachyspermum ammi (L.) Sprague) Seed Extracts in Semi-fried Coated Rainbow Trout (Orcorhynchus mykiss) Fillet for Shelf-life Extention. LWT-Food Sci. Technol., 65, 112121.

Ruiz-Capillas C. Nollet LM (1998). Flow Injection Analysis of Food Addictive. CRC Press. Boca bnaton.

Suwetja IK. 1993. Metode Penentuan Mutu Ikan. Jilid 1. Penentuan Kesegaran. Manado (ID): Universitas Sam Ratulangi

Suwetja IK. 2011. Biokimia Hasil Perikanan, buku. Diterbitkan Oleh Media Prima Aksara. Jakarta. 204h.

Suwetja IK. 2013. Indeks Mutu Kesegaran Ikan (Berkandungan Hasil-hasil Penelitian). Malang (ID): Bayumedia Publishing.

Suyitno dan Kamarijani. 1990. Bahan-bahan Pengemas. PAU Pangan dan Gizi. UGM 